\section{SOI: $1.1 / \mathrm{TAS} \quad$ DOI: $10.15863 / \mathrm{TAS}$ \\ International Scientific Journal Theoretical \& Applied Science}

\author{
p-ISSN: 2308-4944 (print) e-ISSN: 2409-0085 (online) \\ Year: $2016 \quad$ Issue: 2 Volume: 34 \\ Published: 29.02.2016 http://T-Science.org
}

SECTION 25. Technologies of materials for the light and textile industry.
Anna Alexandrovna Demskaya

senior lecturer

Novosibirsk Institute of Technology (branch) «Moscow State Technology and Design University»

a-a-kvasova@ya.ru

Olga Vladimirovna Pischinskaya associate professor, phD,

Novosibirsk Institute of Technology (branch) «Moscow State Technology and Design University»,

Novosibirsk, Russia pischinskaya@mail.ru

\title{
THE TECHNIQUE OF THE EVALUATION OF AESTHETIC PROPERTIES OF FABRICS FOR THE JACKETS OF DIFFERENT PRICE GROUPS
}

Abstract: The paper presents the technique for evaluating the aesthetic properties of the fabric, taking into account the complex index. The technique allows to define conformity of fabric to given price group.

Key words: choice of fabric, price group, aesthetic properties, a complex index.

Language: English

Citation: Demskaya AA, Pischinskaya OV (2016) THE TECHNIQUE OF THE EVALUATION OF AESTHETIC PROPERTIES OF FABRICS FOR THE JACKETS OF DIFFERENT PRICE GROUPS. ISJ Theoretical \& Applied Science, 02 (34): 49-53.

Soi: http://s-o-i.org/1.1/TAS-02-34-8 Doi: crossef http://dx.doi.org/10.15863/TAS.2016.02.34.8

\section{Introduction}

Today the conditions of the market constantly change. Results of work of sewing enterprises depend on accuracy and correctness of choice of the segment of the market for apparel manufacturing. The structure of population needs becomes difficult. Therefore address approach to process of the clothes issue is the most important condition of the sales promotion of the production. The enterprises should reveal clearly determined market segment, his need and expectation for issued production.

To date the selection of materials for clothes is performed using methods for assessing its quality and properties. However, not enough studied the issue of science-based materials for the differentiation of products in different price categories [1, p. 290-292].

To identify the importance of groups of properties of fabric (for example, jackets) for different price categories, conducted expert interviews. The result revealed that the group of aesthetics is a key in selecting fabric into the package of the apparel. Features aesthetic properties partially or completely determined by the subjective perception of the person. The basis of this assessment are the physical properties of the fabrics to be measured [2, p. 128]. Therefore, to evaluate the aesthetic properties of the materials determined their nomenclature which includes: touch, texture, stiffness, drape, stability, and surface coloring material [3, p. 68]. Such properties of the materials must be assessed comprehensively. In connection with this technique complex evaluation of the aesthetic properties of the fabric is designed. The result of this evaluation is to determine the complex index of the aesthetic characteristics of the fabric Yae:

$\mathrm{Yae}=\gamma_{-} 1 * \mathrm{a} 1 * \mathrm{~b} 1+\gamma_{-} 2 * \mathrm{a} 2 * \mathrm{~b} 2+\gamma_{-} 3 * \mathrm{a} 3 * \mathrm{~b} 3+$

$+\gamma_{-} 4 *_{\mathrm{a}} 4+\gamma_{-} \mathrm{T} * \mathrm{y}_{\mathrm{T}}$

where $\gamma_{i}$ - weighting factor of $i$-th aesthetic propertie of the fabric;

$y T$ - complex index of tactile properties of the fabric;

$a i$ - weighting factor score $i$-th aesthetic propertie of the fabric;

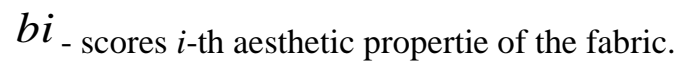

To determine the values of indicators of fabric properties that are part of the complex index of aesthetics, it is necessary to perform five steps (table1).

According to the developed method, the first step is to determine the source data - the thickness of the fabric, surface density of the fabric, the coefficient of tangential resistance, the interlacing of threads in fabric and Surface fabric filling.

Studies by ANOVA, depending installed between the thickness of the fabric, rigidity at material bend and drape coefficient (table 2): 


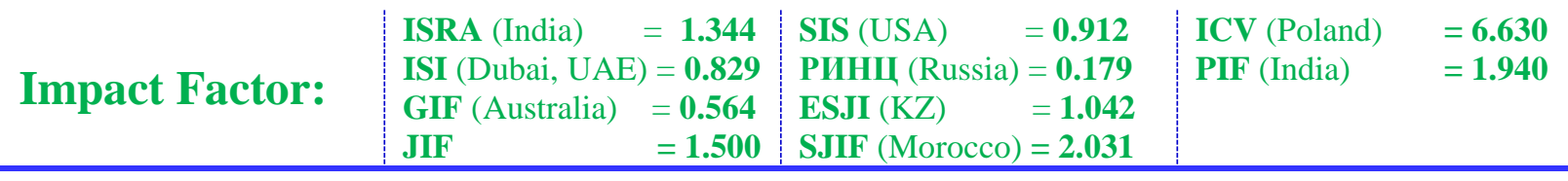

$$
\overline{Y_{x}}=a x+b,
$$

parameters $\boldsymbol{a}$ and $\boldsymbol{b}$ are defined by the formulas:

$$
\begin{gathered}
a=\frac{n \Sigma^{x} m_{x} x \overline{y_{x}}-\Sigma^{x} m_{x} x \Sigma^{x} m_{x} \overline{y_{x}}}{n \Sigma^{x} m_{x} x^{2}-\left(\Sigma^{x} m_{x} x\right)^{2}} \\
b=\frac{\Sigma^{x} m_{x} x \overline{y_{x}} \Sigma^{x} m_{x} x^{2}-\Sigma^{x} m_{x} x \Sigma^{x} m_{x} \overline{y_{x}}}{n \Sigma^{x} m_{x} x^{2}-\left(\Sigma^{x} m_{x} x\right)^{2}},
\end{gathered}
$$

where $\mathrm{x}$ - the thickness of the fabric or surface density of the fabric;

$\mathrm{y}$ - rigidity at material bend;

$m_{x^{-}}$the number of received data for each sample;

$\mathrm{n}$ - the sum of the values obtained $m_{x}$.

As a result, we obtained the regression equation for each price range of materials [4].

\begin{tabular}{|c|c|c|}
\hline № & An action to perform & Received result \\
\hline 1 & 2 & 3 \\
\hline 1 & Definition of the values of initial data & $\begin{array}{l}\text { Surface density of the fabric, } \mathrm{g} / \mathrm{m}^{2} \\
\text { The thickness of the fabric, mm } \\
\text { The interlacing of threads in fabric } \\
\text { Surface fabric filling, } \% \\
\text { The coefficient of tangential resistance of the fabric } \\
\text { Rigidity at material bend, sN } \\
\text { Drape coefficient, \% }\end{array}$ \\
\hline 2 & $\begin{array}{l}\text { Definition of the stability of the fabric surface } \\
\text { abrasion }\end{array}$ & $\begin{array}{l}\text { Score of changes in the surface structure of the } \\
\text { fabric }\end{array}$ \\
\hline 3 & Determination of color fastness of the material & Score of color fastness of the fabric \\
\hline 4 & Definition of fabric invoice & Score of fabric texture \\
\hline 5 & $\begin{array}{l}\text { Calculation of complex index properties of tactile } \\
\text { (handle) of the fabric }\end{array}$ & Score of fabrics handle \\
\hline 6 & Calculation of complex index of fabrics aesthetics & $\begin{array}{l}\text { Score of complex index of fabrics aesthetics. } \\
\text { Determining the price group of fabric }\end{array}$ \\
\hline
\end{tabular}

The technique of the evaluation of aesthetic properties of fabric.

Table 1

The empirical formula depending on the properties of the fabric.

Table 2

\begin{tabular}{|l|l|l|}
\hline \multirow{2}{*}{$\begin{array}{c}\text { The price group of } \\
\text { fabric }\end{array}$} & \multicolumn{2}{c|}{ Regression equations } \\
\cline { 2 - 3 } & \multicolumn{1}{|c|}{ Test sample by lobar thread } & Test sample by weft \\
\hline \multicolumn{1}{|c|}{2} & 3 \\
\hline Dependence stiffness parameters (y) of the fabric thickness $(\mathbf{x})$ \\
\hline High & $\mathrm{y}=0,2 \mathrm{x}+0,7$ & $\mathrm{y}=0,2 \mathrm{x}+0,7$ \\
\hline Middle & $\mathrm{y}=3,4 \mathrm{x}-0,4$ & $\mathrm{y}=3,4 \mathrm{x}-0,4$ \\
\hline Low & $\mathrm{y}=1,8 \mathrm{x}+0,1$ & $\mathrm{y}=0,7 \mathrm{x}+0,7$ \\
\hline The dependence of the values of the drape (y) from the hardness of the fabric $(\mathbf{x})$ \\
\hline High & $\mathrm{y}=-107,1 \mathrm{x}+148,9$ \\
\hline Middle & $\mathrm{y}=-31,5 \mathrm{x}+95,0$ \\
\hline Low & $\mathrm{y}=-84,9 \mathrm{x}+134,1$ \\
\hline
\end{tabular}

At the second stage evaluation of changing the structure of the fabrics surface. Tests produced according to the requirements [5, p.8]. In accordance with the results, given score for fabric (table 3). 


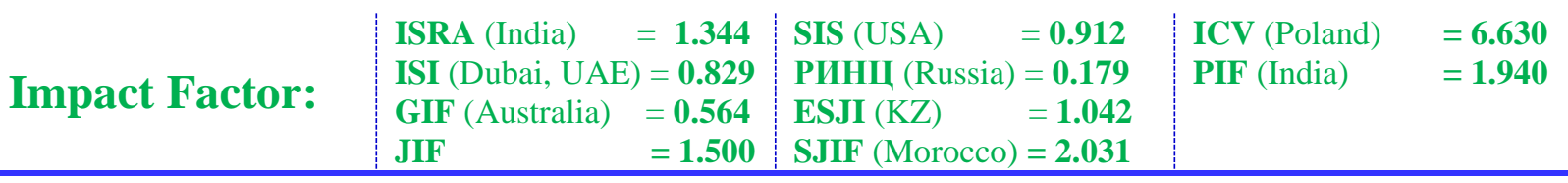

Score changes in the fabrics structure.

Table 3

\begin{tabular}{|l|c|c|c|}
\hline & \multicolumn{2}{|c|}{ Changes in the fabrics structure } \\
\cline { 2 - 4 } & $\begin{array}{c}\text { The appearance of } \\
\text { fluffiness after 100 } \\
\text { cycles }\end{array}$ & $\begin{array}{c}\text { Pilling after 300 cycles } \\
\text { structure }\end{array}$ \\
\hline $\begin{array}{l}3 \text { points - matching } \\
\text { positions }\end{array}$ & - & - & - \\
\hline 2 points - matching 1positions & + & + & + \\
\hline $\begin{array}{l}1 \text { points - matching 2 } \\
\text { positions }\end{array}$ & + & + & + \\
\hline $\begin{array}{l}0 \text { points - matching 3 } \\
\text { positions }\end{array}$ & + & + & + \\
\hline
\end{tabular}

In the third stage material discoloration evaluation by comparing the test sample with a standard. For this test is carried out in accordance with [6, p.7]. Group of color fastness is determined in accordance with a variety of fabrics and assigned scores (table 4).

Score in accordance with the regulatory performance of color fastness of fabric (GOST 9733.0-83).

Table 4

\begin{tabular}{|c|c|c|c|c|}
\hline \multirow[t]{2}{*}{ The assortment fabrics } & \multicolumn{3}{|c|}{ Score } & \multirow{2}{*}{$\begin{array}{l}\text { Weighting } \\
\text { factor score, } \\
a i\end{array}$} \\
\hline & $\begin{array}{l}\text { Ordinary color } \\
\text { fastness }\end{array}$ & Fast & Very fasts & \\
\hline Wool & 1 & 2 & 3 & 0,33 \\
\hline Cotton & - & 1 & 2 & 0,50 \\
\hline Silk & 1 & 2 & 3 & 0,50 \\
\hline Line & - & 1 & 2 & 0,33 \\
\hline
\end{tabular}

In the fourth stage, the texture of the fabric assessment (table 5). During the research the incidence of types of textures is determined for each price category fabrics [7, p. 34-38].

Table 5

Score of fabric texture.

\begin{tabular}{|l|c|c|c|}
\hline \multirow{2}{*}{ Fabric invoice } & \multicolumn{2}{c|}{ Score } & $\begin{array}{c}\text { High } \\
\text { price group }\end{array}$ \\
\cline { 2 - 4 } & $\begin{array}{c}\text { Low } \\
\text { price group }\end{array}$ & $\begin{array}{c}\text { Middle } \\
\text { price group }\end{array}$ & 2 \\
\hline Plain thick & 1 & $\mathbf{3}$ & $\mathbf{3}$ \\
\hline Plain sparsity & 1 & 2 & $\mathbf{3}$ \\
\hline Glare & 1 & 2 & 1 \\
\hline Granular & $\mathbf{3}$ & 2 & 2 \\
\hline Fine fabrics relief & 1 & $\mathbf{3}$ & $\mathbf{3}$ \\
\hline Patterned smooth & 2 & $\mathbf{3}$ & 2 \\
\hline Patterned-relief & 1 & 2 & \\
\hline
\end{tabular}

In the fifth stage of the complex calculation of index of tactile properties of the fabric produced. Tactile properties - a comprehensive description of the fabric, which was offered to evaluate, taking into account the thickness (mm); surface density of fabric $\left(\mathrm{g} / \mathrm{m}^{2}\right)$; the coefficient of tangential resistance of the fabric; rigidity $\left(\mathrm{mkN} \cdot \mathrm{cm}^{2}\right)$; surface fabric filling $(\%)$. The weight of the individual unit properties and their performance largely differ from each other for the products of different price categories.
Calculation of the complex index of tactile properties of the fabric ${ }^{y_{1 k}}$ produced by the formula:

$$
y_{1 k}=\frac{\sum_{i=1}^{n} \gamma_{i}}{\frac{\gamma_{1}}{a_{1}}+\frac{\gamma_{2}}{a_{2}}+\frac{\gamma_{3}}{a_{3}}+\frac{\gamma_{4}}{a_{4}}+\frac{\gamma_{5}}{a_{5}}+\frac{\gamma_{6}}{a_{6}}}
$$




\begin{tabular}{l|lrl|l|ll} 
& ISRA (India) & $=\mathbf{1 . 3 4 4}$ & SIS (USA) & $=\mathbf{0 . 9 1 2}$ & ICV (Poland) & $=\mathbf{6 . 6 3 0}$ \\
Impact Factor: & ISI (Dubai, UAE) $=\mathbf{0 . 8 2 9}$ & PUHIL (Russia) $=\mathbf{0 . 1 7 9}$ & PIF (India) & $=\mathbf{1 . 9 4 0}$ \\
& GIF (Australia) & $\mathbf{0 . 5 6 4}$ & ESJI (KZ) & $=\mathbf{1 . 0 4 2}$ & & \\
& JIF & $\mathbf{1 . 5 0 0}$ & SJIF (Morocco) $=\mathbf{2 . 0 3 1}$ & &
\end{tabular}

where $n$ - number of objective characteristics, included in the complex index;

$\gamma_{i}$ - weighting factor of $i$-th impersonal propertie of the fabric;

$a_{1}$ - the arithmetic mean of the expert evaluation of the degree of conformity of $i$-th impersonal propertie of the fabric to purpose products (price range). [8, p. 74-75].

The results determined in accordance with the scale of assessment of complex tactile indicators fabric (table 6).

Table 6

Scale of assessment of complex tactile indicators fabric.

\begin{tabular}{|c|c|}
\hline Significance & Valuation \\
\hline $0 \div 0,75$ & Excellent \\
$0,75 \div 0,5$ & Good \\
$0,5 \div 0,25$ & Satisfactorily \\
$0,25 \div 0$ & Bad \\
\hline
\end{tabular}

At the sixth stage, the complex index calculation aesthetic properties of the fabric according to the formula 1 , based on scores aesthetic properties of the material and their weighting coefficients (table 7).

Table 7

The properties included in the complex refractive aesthetic properties of the fabric and corresponding coefficients.

\begin{tabular}{|l|c|c|}
\hline \multicolumn{1}{|c|}{$\begin{array}{c}\text { Aesthetic properties of the } \\
\text { fabric }\end{array}$} & Score $i$-th aesthetic propertie, $b \boldsymbol{i}$ & Weighting factor score, $a \boldsymbol{i}$ \\
\hline Drape & $1 \div 3$ & 0,25 \\
\hline Pilling & $1 \div 3$ & 0,25 \\
\hline Texture & $1 \div 3$ & 0,25 \\
\hline Restructuring & $1 \div 3$ & 0,25 \\
\hline Discoloration & $y T, 0 \div 1$ & - \\
\hline Tactile properties & It depends on the variety of fabric & - \\
\hline
\end{tabular}

Establishing a price group of tissue for aesthetic properties, is produced in accordance with the scale of values (table 8).

The scale of values of the complex index of fabrics aesthetic characteristics.

Table 8

\begin{tabular}{|c|c|}
\hline Significance & Estimation \\
\hline $5,0 \div 3,4$ & High \\
$3,3 \div 1,7$ & Middle \\
$1,6 \div 0$ & Low \\
\hline
\end{tabular}

It is assumed that the fabric sample №1 refers to the average price group, the sample №2 - to high. It is necessary to substantiate the alleged price groups fabrics. The results of testing methods for determining the complex index of the aesthetic properties of the fabricl presented in table 9 . 


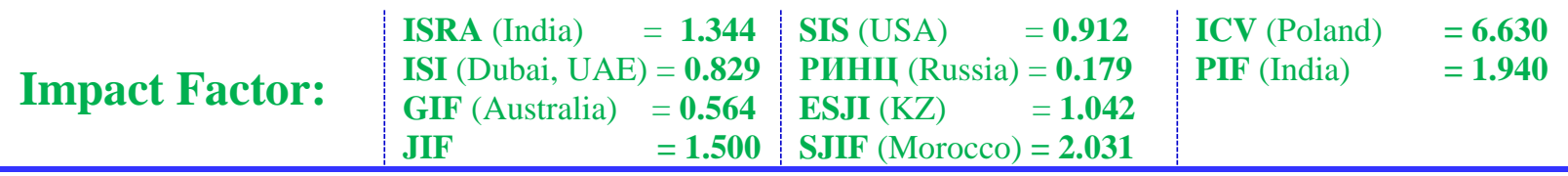

The results of evaluation of test fabrics.

Table 9

\begin{tabular}{|c|c|c|c|c|c|}
\hline \multicolumn{5}{|c|}{ Fabrics properties } & \multirow{3}{*}{$\begin{array}{l}\text { The complex index of the } \\
\text { aesthetic characteristics } \\
\text { of the fabric, } \mathrm{y}_{\mathrm{ae}}\end{array}$} \\
\hline \multicolumn{2}{|l|}{ Source data } & \multicolumn{3}{|c|}{ Finding } & \\
\hline Designation & Value & Designation & Value & Score & \\
\hline 1 & 2 & 3 & 4 & 5 & 6 \\
\hline \multicolumn{6}{|c|}{ The fabric sample №1 } \\
\hline $\begin{array}{l}\text { Surface density of fabric } \\
\mathrm{Ms}, \mathrm{g} / \mathrm{m}^{2}\end{array}$ & 215 & handle & 0,80 & 0,80 & \multirow{6}{*}{3,35} \\
\hline $\begin{array}{l}\text { The coefficient of tangential } \\
\text { resistance of the fabric }\end{array}$ & 0,5 & texture & glare & 0,33 & \\
\hline Surface fabric filling, $\%$ & 89,80 & $\begin{array}{l}\text { resistant fabric } \\
\text { surface }\end{array}$ & not detected & 1 & \\
\hline Rigidity at material bend, sN & 0,90 & drape & 57,7 & 0,66 & \\
\hline $\begin{array}{l}\text { The thickness of the fabric, } \\
\mathrm{mm}\end{array}$ & 0,4 & \multirow{2}{*}{$\begin{array}{l}\text { color fastness } \\
\text { of the fabric }\end{array}$} & \multirow{2}{*}{$\begin{array}{l}\text { strong } \\
\text { coloring }\end{array}$} & \multirow{2}{*}{0,66} & \\
\hline $\begin{array}{l}\text { The interlacing of threads in } \\
\text { fabric }\end{array}$ & satin & & & & \\
\hline \multicolumn{6}{|c|}{ The fabric sample №2 } \\
\hline $\begin{array}{l}\text { Surface density of fabric } \\
\mathrm{Ms}, \mathrm{g} / \mathrm{m}^{2}\end{array}$ & 215 & handle & 0,97 & 0,97 & \multirow{6}{*}{4,63} \\
\hline $\begin{array}{l}\text { The coefficient of tangential } \\
\text { resistance of the fabric }\end{array}$ & 0,45 & texture & glare & 1 & \\
\hline Surface fabric filling, $\%$ & 91,12 & $\begin{array}{l}\text { Устойчивость } \\
\text { поверхности } \\
\text { материала }\end{array}$ & $\begin{array}{c}\text { образование } \\
\text { пиллей }\end{array}$ & 0,66 & \\
\hline Rigidity at material bend, $\mathrm{sN}$ & 0,979 & drape & 65,31 & 1 & \\
\hline $\begin{array}{l}\text { The thickness of the fabric, } \\
\mathrm{mm}\end{array}$ & 0,4 & \multirow{2}{*}{$\begin{array}{l}\text { color fastness } \\
\text { of the fabric }\end{array}$} & \multirow{2}{*}{$\begin{array}{l}\text { rugged } \\
\text { coloring }\end{array}$} & \multirow{2}{*}{1} & \\
\hline $\begin{array}{l}\text { The interlacing of threads in } \\
\text { fabric }\end{array}$ & satin & & & & \\
\hline
\end{tabular}

Assessing the complex indexes, we can say the conclusion that the tested samples correspond to the stated price group for aesthetic properties.

Thus, the developed method allows to determine how this fabric it meets the requirements of a given consumer price segment. The developed technique allows evaluation of the fabric to create a database in which the selection of the fabric can be carried out in an automated way. This will allow us to carry out technical training of production for each of the selected prices categories of apparel.

\section{References:}

1. Mokeeva NS (2009) Noviy podhod k proektirovaniyu tekhologicheskih processov izgotovleniya muzskih koctyumov / Molodie uchenie - razvitiyu textilnoy i legkoi promishlennosti (Poisk - 2009). Part 1. Ivanovo: IGTA, pp. 316.

2. Buzov BA (2004) Materiali v legkoi promishlennosti (shveinaya promishlennost). Moscow: pp. 448.

3. Buzov BA (2010) Materiali dlya odezdi. Moscow: Publishing Center "Academy", pp. 160 .
4. (2015) Least-squares method. Available: https://ru.wikipedia.org/wiki (Accessed: 26.12.2015).

5. (2012) GOST R ISO 12945-2-2012. Textile materials. Determination of textile capacity to the formation of hairiness and pilling.

6. (1999) GOST R ISO 105-A01-99. Textile materials. Determination of color fastness.

7. Buzov BA (2012) Materiali dlya odezdi. Tkani - Moscow: Publishing House «Forum». -pp. 224.

8. Sklyannikov VP (1983) Stroenie I kachestvo tkaney. - Moscow: Light \& Food Industry. pp. 232 . 